\author{
Ольга іггус Olha Lihus \\ кандиАат мистецтвознавства, Аоцент кафедри музикознавства \\ та музичної освіти Інституту мистецтв Київського університету \\ імені Бориса Грінченка \\ PhD in Art Studies, Assistant Professor at the Department \\ of Musicology and Musical Education, Institute of Arts, Borys \\ Grinchenko Kyiv University
}

\title{
Тенденції неоромантизму в українській фортепіанній музиці початку XX століття
}

\author{
Neoromantic Tendencies in the Ukrainian \\ Piano Music of the Early $20^{\text {th }}$ Century
}

\begin{abstract}
Анотація. Простежено прояв тенденцій неоромантизму в українській фортепіанній музиці початку XX століття на прикладі вальсів Я. Степового та ноктюрнів В. Косенка. Ці твори розгляАаються у контексті стильових пошуків захіАноєвропейських та російських композиторів епохи fin de siecle. Методологія досліАження охоплює загальні та спеціальні наукові методи: історичний (у проведенні аналізу суспільно-політичних процесів кінця XIX — початку XX століття); історико-культурний (у розгляАі художньо-естетичних засаА тогочасної європейської музичної культури); теоретичний метоА моделювання (у вияві анамогій між втікенням принципів неоромантизму в українській та зарубіжній музиці); компаративний (у визначенні спільних та відмінних жанрово-стилістичних рис у фортепіанних творах українських та зарубіжних митців). На піАставі порівняльного аналізу в розглянутих творах виявлено типологічно спільні ознаки неоромантизму, виокремлено інонаціональні впливи, визначено віАмінні жанрово-стилістичні риси, які констатують оригінальність неоромантичного мислення українських композиторів початку XX століття.

Ключові слова: неоромантизм; романтизм; fin de siecle; українська музика; фортепіанна музика XX століття.
\end{abstract}

Постановка проблеми. Сучасне музикознавство наАає важливого значення осмисленню українського музичного мистецтва в контексті європейської культури. У зв'язку з цим актуалізується проблема стильової специфіки творчості вітчизняних композиторів різних художньо-історичних епох, аАже стиль - це те, в чому схоплюється не мише оригінальність і неповторність, а й цілісність аналізованих явищ, тобто базова властивість Аля розкриття української музики як суб'єкта європейського культурного світу.

Означена проблема набуває ваги в ракурсі досліАження музично-історичного процесу початку XX століття, що характеризується яскравим спацахом мистецького індивіАуалізму, що характерно також Аля творчості українських композиторів (М. Аеонтовича, К. Стеценка, Ф. Якименка, Я. Степового, В. Косенка, С. Аюдкевича та інших). Це обумовлено різновекторними тенденціями епохи fin de siecle: імпресіонізму, символізму, експресіонізму. Водночас творчість цих митців єАнає спільна Ауховно-естетична тональність, яка визначияа образно-тематичні, Араматургічні, формотворчі та стилістичні пріоритети художнього письма. Саме на цьому стильовому піАгрунті формувалися принципи нового, моАерного, українського музичного мистецтва, що Аосягло еволюційної вершини у АваАцятих роках ХХ стоміття. ЙАеться переАусім про творчість В. Барвінського,
Б. Аятошинського, А. Ревуцького, А. Руаницького, М. Росмавця. Тому визначення стильової домінанти творчості українських композиторів перших десятиліть XX століття Уявцяється вельми важливим етапом Аля розуміння глибинних процесів розвитку вітчизняного мистецтва в контексті загальноєвропейського музично-історичного процесу.

Особливо виразно стильова єАність простежується у фортепіанній музиці - пріоритетній жанровій сфері тогочасного творчого процесу. ВіАповіАно, ААЯ розкриття стильової специфіки українського музичного мистецтва початку XX століття об'єктом розгляду обрано саме фортепіанні твори.

Анаміз останніх досліджень і публікацій. Стильовим аспектам української фортепіанної музики початку XX стоміття ще не присвячено спеціальних досліАжень, хоча фортепіанний Аоробок Аеяких композиторів тієї Аоби, а також окремі жанри і твори було проаналізовано в музикознавчих працях різної проблематики. Так, $\Lambda$. Аанцута, розглянувши фортепіанні сонати $\Lambda$. Ревуцького, Я. Степового, В. Барвінського та В. Косенка, виявила в них національно-романтичні стильові ознаки [4]. Інша Аослідниця цього жанру, О. Чабан, зосередила увагу на творчості західноукраїнських композиторів, виявивши в їхніх сонатах прояви символізму [7]. Фортепіанні мініатюри різних жанрів означеного 
часу ввійшли до аналітичного матеріалу монографії авторки цієї статті, в якій досліАжувалася українська фортепіанна музика епохи романтизму [5]. Образно-тематичні та жанровостилістичні аспекти фортепіанної спадщини С. Аюдкевича висвітлено в монографії Г. Брилинської-Блажкевич [1], а В. Барвінського - у Аисертації $\Lambda$. Назар, присвяченій стиАьовим особливостям творчості цього митця [6].

ЗАебільшого, у фортепіанній музиці українських митців початку XX століття всі АосліАники справеАливо віАзначають взаємодію різних стильових тенденцій на основі романтичної традиції. При цьому в деяких характеристиках стилю спостерігається термінологічна строкатість [6, с. 13], а також інтерпретаційність при оперуванні поняттями і термінами $[7$, с. 8], що, ймовірно, зумовлено об’єктивною склаАністю стильової атрибуції творчості як у межах певного композиторського Аоробку, так і всього історичного періоду.

У пошуках термінологічної коректності оптимальним видається піАхіА $\Lambda$. Корній, яка, узагальнюючи стильову картину розвитку української музики Сходу і Заходу початку XX століття, використовує термін «неоромантизм» [3]. Такий піАхіА корелює з науковими позиціями захіАних музикознавців різних покомінь: К. Аальгауза [8], С. ПеАерсон [10] та Г. Паулса [9], які послуговуються цим терміном у визначенні музичного стилю кінця XIX — початку XX століття. Зокрема, американська дослідниця С. Педерсон вважає, що «Аруга хвиля романтизмучи то “неоромантизму” тривала Ао початку Першої світової війни» [10, с. 171].

Сучасний німецький музикознавець Г. Паулс трактує неоромантизм значно ширше, постулюючи іАею актуальності романтичного стилю протягом усього ХX століття, зокрема й у перші Аесятиліття: «Неоромантична категорія виявилася Ауже стійкою, це “узагальнювальний термін”, до якого причетні різні композитори, навіть ті, що позиціонували себе як авангардисти періоду “холоАної війни”. Майже кожен композитор початку XX століття, хоч би яким радикальним він був, створював опуси або хоча би пасажі у романтичному стимі $>$ [9, с. 150].

Беручи до уваги наведені аргументи, визначення стимьової специфіки української фортепіанної музики початку XX століття уявляється Аоцільним з погляАу неоромантизму.

Мета статті - виявити тенденції неоромантизму в українській фортепіанній музиці початку XX століття. Проблема досліАжуватиметься на прикладі вальсів Я. Степового та ноктюрнів В. Косенка, які аналізуватимуться у контексті стильових пошуків захіАноєвропейських та російських композиторів-сучасників. Вибір аналітичного матеріалу обумовлений як критерієм виразності прояву неоромантичних тенденцій, так і необхіАністю висвітлення маловивчених аспектів історії української музики, сереА яких, зокрема, творчість Я. Степового та В. Косенка.

ВикмаА основного матеріалу. Період 1890-1910-х увійшов в історію як «епоха fin de siecle», що віАображама характерне світовідчуття, пов'язане з реакцією суспільства на кризові явища в соціокультурному житті Європи. Характерні ознаки цього світовідчуття - психологічне сум'яття та страх переА майбутнім, що їх влучно уза- гальнив німецький філосо $Ф$. Ніцше знаменитою тезою про «загибель Бога».

Емоційно напружена атмосфера спричинила попит на мистецтво ірраціональне, рафіноване, позбавлене пафосу суспільної значущості, властивого культурі попередньої Аоби Романтизму. ЗвіАси - характерне Аля творчості цього періоАу тяжіння Ао психологізму, містицизму, туга за недосяжним іАеалом, віАповіАно, микування красою, чарівними образами, захоплення естетизмом. При цьому панівною образноемоційною сферою творчості залишалася мірика, виявцяючи безпосередній зв'язок із романтичною естетикою. Крім того, весь арсенал виражальних засобів мистецтва цієї доби базувався, здебільшого, на стильовій палітрі романтизму.

Невипадково, вже в той час у західноєвропейських арт-колах в ужиток увійшов термін «неоромантизм» ${ }^{1}$, який став умовною стильовою Аефініцією сукупності новітніх різноспрямованих художніх тенденцій, генетично пов'язаних із романтичним стилем: імпресіонізму, симвомізму, сецесії, експресіонізму. Всі означені художні течії переважно стверАжували культ підвищеного індивідуалізму, що в оАних випадках виявцявся нестримним відчуттям свободи, повноти і барвистості життя, в інших - песимістичними настроями розчарування, апатії та фаталізму. Тому в різних національних музичних культурах цього часу виникають полярні за образним змістом та емоційно-енергетичним зарядом стильові явища: одухотворені імпресіоністичні пейзажі фортепіанних прелюдій та симфонічних композицій К. Аебюссі, апокаліптичні концепції монументальних симфоній Г. Малера, пронизані експресіоністичним відчуттям втраченої гармонії, витончено-примхливі химерні образи-символи поем О. Скрябіна, що ніби розчиняються у фактурному плетиві мерехтливих гармоній, сповіАальна щирість та водночас бурхливий Араматизм фортепіанних та симфонічних полотен С. Рахманінова, фольклорна характеристичність мініатюр Е. Гріга з притаманними його стилю Ааконізмом вислову, ритмічною пружністю і свіжістю гармонічних барв. Аоволі часто таку контрастність бачимо у творчості оАного композитора, навіть в оАному творі.

Всеосяжність образно-емоційної палітри неоромантизму обумовила зміни всередині жанрової системи. Кумьт програмності, створений романтиками у XIX столітті, тепер витісняється пієтетом «чистих» жанрів, що мають універсальну зАатність до гнучких переосмислень та модифікацій залежно віА творчого задуму. Пріоритетне місце посіАають жанри інструментальної музики, які акумулюють широкі технічні можливості Аля втілення найтонших тембрових, мелодико-інтонаційних і тонально-гармонічних нюансів образного змісту. При цьому спостерігається прихильність композиторів як Ао граничної камерності вислову, реалізованої в межах маконічної інструментальної мініатюри, так і до безкінечної плинності імпровізаційних форм сольно-ансамбцевого та симфонічного складу.

1 Термін «неоромантизм» виник у мітературі в останній чверті XIX століття у Франції й Німеччині, деАалі поширюючись АвстроУгорщиною, Росією, Україною й Польщею. В Україні його вперше ввема Ао мітературознавчого обігу Аеся Українка («новоромантизм»). 
Стильові тенденції епохи fin de siecle виразно відбимися в українській фортепіанній музиці початку XX стоміття. ПоАібно Ао європейських неоромантиків, українські композитори надають перевагу безпрограмним жанрам фортепіанного репертуару XIX століття (Аіричним і танцювальним мініатюрам, поемам, фантазіям тощо), наповнюючи їх новим змістом і смислом. Опуси Я. Степового (Вальси h-moll op. 5, № 1; d-moll op. 7, № 5) та В. Косенка (Ноктюрн-фантазія cis-moll op. 4; ноктюрн fis-moll op. 9, № 3) - у річищі цих тенденцій.

Розгляа Авох вальсів Я. Степового виявив у цих творах нову якість стилю, утворену органічним синтезом ознак романтизму та імпресіонізму. Про вплив романтичної традиції свідчить, передусім, жанровий вибір митця, аАже саме вальс, найпопулярніший міричний танець ХІХ століття, посів особмиве місце у фортепіанній творчості виАатних митців тієі епохи: Ф. Шуберта, Ф. Шопена, Й. Брамса, П. Чайковського. Спадкоємний зв'язок із романтичною модемлю жанру проявляється у наслідуванні загальних жанрових параметрів: семантики вальсу з їі жіночим началом, вираженим тридольним метром та м'якими мелодичними інтонаціями «кружмяння», а також у використанні Я. Степовим типової будови камерних вальсів Ф. Шопена — тричастинної репризної форми з контрастною серединою.

Зберігаючи у своїх вальсах зовнішні ознаки романтичної традиції, український композитор, проте, наділяе ці п’єси Аоволі нетиповою емоційною барвою. Образний зміст вальсів, хоч і навіяний міричною стихією, аме позбавмений характерної Аля цього жанру заАушевно-проникливої журмивості чи то піднесеної схвильованості. Панівна емоційна тональність цих творів - стримана споглядальність, забарвлена нервово-примхливими нотками або пейзажно-комористичними відтінками, близькими до імпресіоністичної памітри образно-виразових засобів.

Неоромантична якість міризму вальсів Я. Степового Аосягається використанням комплексу стильових ознак (як образно-змістових, так і логіко-конструктивних та стимістичних), притаманних музичній творчості епохи fin de siecle. У процесі аналізу обох п'єс виявилося чимало поАібностей із художнім письмом Е. Гріга, що пояснюється як типологічно спільним характером стильового мислення обох митців, так і орієнтацією Я. Степового на музичну мову норвезького композитора. Зокрема, у цих творах простежуються такі характерні Аля музики Е. Гріга особливості: мініатюризм, народно-жанрова скерцозність, особливий характер міричного вислову (часом примхливий, а Аеколи стримано-споглядальний), пейзажна барвистість.

Мініатюризм як типова ознака неоромантичного мисмення проявився у вальсах Я. Степового на різних рівнях, передусім, на композиційному і фактурному. Подібно до багатьох фортепіанних творів Е. Гріга і зокрема, його вальсів-мініатюр (a-moll op. 12, № 2 та e-moll op. 38, № 7), кожна 3 Авох п'єс українського митця має Аоволі стислу композицію, яка розгортається шляхом чергування і повтору коротких тематичних утворень. Крайні розАіли вальсів Я. Степового побудовано на розвитку одного образно-емоційного стану, гранично сконцентрованого в основній темі твору, яка ви- різняється маконізмом вислову, кваАратністю структури, Арібністю фразування, повторністю тематичних елементів.

Принцип мініатюризму визначив і специфіку фактури вальсів Я. Степового, Аля якої характерні стриманість, «зібраність», простота і прозорість виклаАу, так само як і дмя фактури багатьох фортепіанних п’є норвезького композитора, призначених Амя камерного виконання. Окрім того, у вальсах українського неоромантика спостерігається чимало типових Аля стилю Е. Гріга фактурних прийомів. Зокрема, спільний фактурний малюнок зближує основні теми Вальсу ор. 5, № 1 Я. Степового та a-moll'ного вальсу норвезького композитора. Обидва твори єАнає і фактурна формула «хоралу» народно-жанрового за-

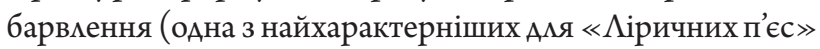
Е. Гріга), яку Я. Степовий використовує у сереАньому розАілі. Інший тип фактури - своєріАні регістрові «перегуки», що їх бачимо в обох вальсах українського митця (у розвиткових фрагментах середнього роздіку переА репризою) - також є типовим Амя багатьох творів Е. Гріга, зокрема, Аля Вамьсу-капрису ор. 37, № 1.

Свідченням споріАненості художнього письма Я. Степового та Е. Гріга $є$ спільні ознаки стилістики: мемодичне обігравання тонічної квінти, особлива увага до басових формул ostinato, часте використання пунктирів, микування терпкими гармонічними утриманнями в різних шарах фактурної тканини, піАкреслення контрастів між Аіатонічними і рясно-хроматичними епізодами, схильність Ао гармонічної барвистості. Остання детамь - характерна ознака імпресіоністичного мислення Е. Гріга, яка найвиразніше проявилася в основній темі Вальсу ор. 7, № 5 українського композитора у вигляАі яскравого секвенційного манцюга еліптичних зворотів. Спільними рисами музичної мови вальсів обох митців $є$ також мелодична формула 3 короткими секундовими утриманнями, і врешті, специфічний «грігівський» зворот із низхіАним рухом мелодії I - VII - V з типовим народно-жанровим озАобленням так званої «волинкової квінти», що його Я. Степовий використовує в сереАній частині свого Вальсу ор. 5, № 1.

ПіА знаком неоромантизму розвивалася і фортепіанна творчість В. Косенка, який суттєво збагатив новими хуАожніми барвами інший провіАний жанр епохи романтизму - ноктюрн. Характерні ознаки цього міричного жанру (камерність форми, невимушеність розгортання міричного вислову, свобода у використанні технічного потенціалу інструмента та яскрава барвистість у відтворенні поетичних картин нічної природи), які викристалізувалися у творчості кількох поколінь композиторів XIX століття, відтворилися У Авох ноктюрнах українського митця крізь призму романтичної традиції та символістських пошуків епохи fin de siecle.

Як і більшість опусів «житомирського ґ періоду творчості В. Косенка (1919-1924 роки) обидва його ноктюрни сповнені різноманітних міричних віАтінків романтичного почуття: щемливої ніжності, Араматичної схвильованості та мрійливої споглядальності ${ }^{1}$ У кожному творі

${ }^{1}$ Ноктюрн fis moll (op. 9, № 3) композитор присвятив своїй майбутній Аружині А. В. Косенко. 
панує певна емоційна тонамьність: у Ноктюрні-фантазіїмірико-драматична, а в Ноктюрні fis-moll - елегійна.

СпоріАненість із романтичним стилем виявцяється в ноктюрнах В. Косенка на рівні узагальнення характерних ознак жанрової моделі Ф. Шопена. Так само як і польський романтик, В. Косенко у своїх творах тяжіє Ао емоційної цімісності образу з характерним поєАнанням драматичного та елегійного начал, тричастинної репризної форми, інтимно-проникливого характеру висловлювання, трактування фортепіано як «співучого» інструмента, яскраво-колористичної гармонії. Крім того, в Ноктюрні-фантазії відбилася типова стилістична особливість шопенівської традиції жанру - орнаментальний розвиток мелодії (т. 8-10), притаманна багатьом ноктюрнам польського романтика.

Водночас, в обох творах В. Косенка відчутні характерні мотиви символізму, властиві творчості багатьох композиторів-сучасників: сповіАацьно-ностальгічний характер, примхливість, ефемерність міричного образу. За своїм змістом, композиційними ознаками та музичною мовою ноктюрни українського неоромантика $€$ типологічно близькими до міричних фортепіанних п’єс російських композиторів тієї Аоби: В. Каміннікова, С. Рахманінова, i, особливо, О. Скрябіна, Ао творчості якого В. Косенко завжАи виявцяв особливий інтерес.

Рецепція символістського стилю О. Скрябіна проявцяється в ноктюрнах українського митця на рівні засвоєння окремих Араматургічних принципів та стикістичних прийомів. Так само, як в О. Скрябіна, розуміння В. Косенком поемності розвитку художнього образу пов'язане з характерним відчуттям музичного простору як безмежного цілого. ЗвіАси - плинність, імпровізаційність музичної Аумки, зумовлена широким використанням принципів варіювання, перегармонізації, а також інтенсивним секвенційним рухом. У творчості обох композиторів це призвело Ао розширення жанрових меж ноктюрна, який в О. Скрябіна перетворився на Поему-ноктюрн, а у В. Косенка — на Ноктюрн-фантазію.

Зі скрябінськими творами обидва ноктюрни українського композитора єАнає й особливий тип міричного висловлювання, в якому органічно зАилися імпульси різноріАних стихій: вокальне й інструментальне, співоче й танцювальне, «ліричне одкровення та гра» [2, с. 363]. У Ноктюрні-фантазії В. Косенка інтонації драматичного речитативу переходять у вишукану арабеску, а в Ноктюрні fis-moll мотиви меланхомійного вальсу та щемливої сповіАі ніби «розчиняються» у примхливій грі.

Подібно до О. Скрябіна, український композитор сприймав музичний образ ніби крізь завісу зачарованості, милування, намагаючись віАтворити найтонші деталі його поступового проростання. Ймовірно тому в композиціях обох митців особливу увагу звернено на еліптичні посліАовності (що створюють ефект плинності руху), на Аетамізацію звукового колориту та розподіл гармонічних тонів всією фактурною тканиною (так звана «гармоніє-мелоАія» О. Скрябіна). СереА найулюбленіших спільних гармоній О. Скрябіна та В. Косенка - амьтеровані різновиди нонакорду із секстою, які український неоромантик часто використовує у розвиткових фрагментах своїх ноктюрнів.
Чимало спільного зі скрябінським стилем простежується також у мелодиці ноктюрнів В. Косенка з їі ритмічною та метричною мінливістю (Ноктюрн fis-moll). Порівняння обох творів з фортепіанними мініатюрами О. Скрябіна раннього періоду творчості дало змогу визначити спільну ритмо-інтонаційну ознаку, характерну Аля стилю обох композиторів: тріольність у поєАнанні з пунктирним ритмом. СпоріАнює мелодії творів обох митців і використання специфічної формули - низхідної інтонації з предйомом (кварти, терції або сексти).

Висновки. Фортепіанна творчість Я. Степового та В. Косенка віААзеркалює перехіАний характер розвитку вітчизняного музичного мистецтва початку ХХ століття, обумовлений стильовою неодноріАністю музично-історичного процесу епохи fin de siecle. РозгляА вальсів Я. Степового та ноктюрнів В. Косенка в контексті художніх пошуків композиторів-сучасників Аав змогу виявити у цих творах тенденції неоромантизму, що характеризується органічним синтезом стильових компонентів творчості попередньої епохи та початку XX століття.

3 першим компонентом пов'язано звернення українських митців Ао типових жанрів фортепіанної музики Аоби романтизму з наслідуванням образно-тематичних та композиційних жанрових ознак. Інший компонент має протилежний «заряА», обумовлений прагненням подомати стильові рамки романтизму, віАгукуючись на різноспрямовані образно-емоційні, Араматургічні та стилістичні тенденції художнього письма епохи fin de siecle. У вальсах Я. Степового відобразилися такі характерні ознаки музичної творчості XX століття, як рафінованість образно-емоційного змісту, мініатюрність форми та афористична стислість висловлювання. ВіАмінний напрям стильового оновлення обрав В. Косенко, ноктюрни якого увібрали гіпертрофовану чуттєвість, загострено-нервове відчуття неповторності та плинності моменту, нестримну експресію і Аинамізм почуттів.

У річищі неоромантичних пошуків обиАва українські митці спиралися на Аосягнення композиторів інонаціональних шкіц, із творчістю яких виявляється чимало типомогічних аналогій (у вальсах Я. Степового простежуються імпресіоністичні принципи стилю Е. Гріга, в ноктюрнах В. Косенка - символістські риси творчості О. Скрябіна). Ці зближення є свідченням спільності художніх процесів у різних музичних культурах того часу, а також творчого переосмислення стильового АосвіАу музичного мистецтва своєї епохи.

Неоромантична якість художнього мислення українських композиторів змінила жанрову сутність їхніх творів. Трансформація образно-емоційної сфери вальсів Я. Степового призвела Ао руйнації міричної мелодійності, значно послабивши зв'язок із жанровою традицію вальсу епохи Романтизму. Свободою жанрового трактування вирізняються і ноктюрни В. Косенка (зокрема, Ноктюрнфантазія), що втратили характерний Аля «нічної пісні» умиротворено-спогляАальний Аіризм, втілюючи піАнесений тонус трепетного очікування, інспірований бурхливим Аухом епохи fin de siecle. 


\section{Мітература}

1. Брилинська-Блажкевич Г.Й. Фортепіанна творчість С. вича: монографія. Аьвів: ВМІ імені М. Аисенка, 1999. 234 с.

2. Зенкин К.В. Фортепианная миниатюра и пути музыкального романтизма: учебник Аля вузов. 2-е изА. Москва: Юрайт, 2019. 413 с. 3. Корній $\Lambda$. П. Історія української музичної кумьтури віА Аавнини Ао початку XX століття: монографія. Київ: Муз. Україна, 2018. 362 с. 4. Аанцута $\Lambda$.В. Українська фортепіанна соната: теорія, історія, сучасні тенденції: автореф. Аис. ... канд. мистецтвознав.: 17.00.03. Київ, 1998. 18 с.

5. Мігус О.М. Українська фортепіанна музика XIX - початку $\mathrm{XX}$ ст. у контексті європейського романтизму: жанрово-стильова Аинаміка: монографія. Київ: Аіра-К, 2017.224 с.

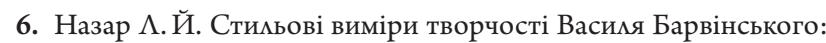
автореф. Аис. на зАобуття наук. ступеня канА. мистецтвознав.: 17.00.03. Аьвів, 2007. 19 с.

7. Чабан Т.І. Стимьові засади символізму в сонатах західноукраїнських композиторів кінця XIX-першої половини XX століття: автореф. Аис. на зАобуття наук. ступеня канА. мистецтвознав.: 17.00.03. OAeca, 2019. 18 c.

8. Dahlhaus C. Neo-Romanticism // 19th-Century Music. 1979. Vol. 3, No. 2. pp. 97-105.

9. Pauls H. Two centuries in one. Musical Romanticism and the twentieth-century. Ph.D. Thesis. Rostock University of Music and Theatre, 2014. $478 \mathrm{p}$.

10. Pederson S. Romanticism/anti-romanticism // Aesthetics of Music: Musicological Perspectives. Routledge, 2014. pp. 170-187.

\section{References}

1. Brylynska-Blazhkevych, G.J. (1999) Fortepianna tvorchist S. Lyudkevycha: monografiya. Lviv: VMI imeni M. Lysenka.

2. Zenkin, K.V. (2019) Fortepiannaya miniatyura i puti muzyikalnogo romantizma: uchebnik dlya vuzov, $2^{\text {nd }}$ ed. Moscow: Yurayt.

3. Kornij, L.P. (2018) Istoriya ukrayinskoyi muzychnoyi kultury vid davnyny do pochatku XX stolittya: monografiya. Kyiv: Muz. Ukrayina.

4. Lanczuta, L.V. (1998) Ukrayinska fortepianna sonata: teoriya, istoriya, suchasni tendenciyi. Abstract of Ph.D. dissertation. NMAU im. P. I. Chajkovsкogo.

5. Ligus, O.M. (2017) Ukrayinska fortepianna muzyka XIX - pochatku XX st. u konteksti yevropejskogo romantyzmu: zhanrovo-stylova dynamika. Kyiv: Lira-K.

6. Nazar, L.J. (2007) Stylovi vymiry tvorchosti Vasylya Barvinskogo. Abstract of Ph.D. dissertation. LDMA im. M. V. Lysenka.

7. Chaban, T. I. (2019) Stylovi zasady symvolizmu v sonatax zaxidnoukrayinskyx kompozytoriv kincya XIX-pershoyi polovyny XX stolittya. Abstract of Ph.D. dissertation. ONMA im. A.V. Nezhdanovoyi.

8. Dahlhaus, C. (1979) 'Neo-Romanticism', 19th-Century Music, 3 (2), pp. 97-105.

9. Pauls, H. (2014) Two centuries in one. Musical Romanticism and the twentieth-century. Ph.D. Thesis. Rostock University of Music and Theatre. Rostock, Germany.

10. Pederson, S. (2014). 'Romanticism/anti-romanticism' in S. Downes (ed.) Aesthetics of Music: Musicological Perspectives. London; New York: Routledge, 2014, pp. 170-187.

Lihus $\mathbf{O}$.

Neoromantic Tendencies in the Ukrainian Piano Music of the Early 20th Century

Abstract. The article focuses on the examination of neoromantic tendencies in the Ukrainian piano music of the turn of the $20^{\text {th }}$ century by the example of the waltzes by Ya. Stepovyi and nocturnes by V. Kosenko. These musical pieces are viewed in the context of the stylistic findings of the Western European and Russian composers of the fin de siecle era. The research methodology incorporates general and specific scientific methods: historical method (to analyze social-political processes of the $20^{\text {th }}$ century turn); historical-cultural method (to consider the artistic-aesthetical foundations of European musical culture of that period); theoretical method of modelling (to reveal the analogies of the embodiment of the neoromantic principles in the Ukrainian and foreign music); comparative (to define similar and distinct genre-stylistic features of the piano pieces of the Ukrainian and foreign composers). Basing on this comparative analysis, typologically common features of Neoromanticism are defined, foreign influences are determined, distinct genre-stylistic features are considered that demonstrate the uniqueness of the neoromantic thinking of the Ukrainian composers of the turn of the $20^{\text {th }}$ century. Keywords: Neoromanticism, Romanticism, fin de siecle, Ukrainian music, $20^{\text {th }}$-century piano music.

Аигус О.

Тенденции неоромантизма в украинской фортепианной музыке начала XX века

Аннотация. Исследовано проявление тенденций неоромантизма в украинской фортепианной музыке начала XX века на примере вальсов Я. Степового и ноктюрнов В. Косенко. Эти произведения рассматриваются в контексте стикевых исканий западноевропейских и российских композиторов эпохи fin de siecle. Методомогия исследования охватывает общие и специальные научные методы: исторический (в анализе общественно-политических процессов конца XIX — начала XX века); историко-культурный (в рассмотрении художественно-эстетических основ европейской музыкальной культуры того времени); теоретический метоА моделирования (при выявлении аналогий межАу воплощением принципов неоромантизма в украинской и зарубежной музыке); компаративный (в определении общих и отличительных жанрово-стилистических черт фортепианных произведений украинских и зарубежных композиторов). На основании сравнительного анализа в рассмотренных произведениях выявлены типологически общие признаки неоромантизма, выдемены инонациональные влияния, определены отличительные жанрово-стилистические черты, которые констатируют оригинальность неоромантического мышления украинских композиторов начала XX века. Ключевые слова: неоромантизм, романтизм, fin de siecle, украинская музыка, фортепианная музыка XX века. 